\title{
Demographic Statistics among Pashtuns in Early Modern Period
}

\author{
M. S. Pelevin
}

St. Petersburg State University, 7-9, Universitetskaya nab., St. Petersburg, 199034, Russian Federation

For citation: Pelevin M.S. Demographic Statistics among Pashtuns in Early Modern Period. Vestnik of Saint Petersburg University. Asian and African Studies, 2019, vol. 11, issue 1, pp. 64-74. https://doi. org/10.21638/spbu13.2019.105

The article explores rare specimens of demographic statistics extracted from the seventeenth century works in Pashto and Persian which were composed in the Pashtun tribal territories. The study's major source is the collection of historical accounts and genealogical records written by the Khatak tribal rulers Khushḥāl Khān (d. 1689) and his grandson Afżal Khān (d. circa 1740/41). These writings have survived in "The Khataks' Chronicle" - the archive of the Khatak chieftains included by Afżal Khān as a supplement into his historiographical compilation "The Ornamented History" (Tärīkh-i murașsa). Other sources are the poetical works of Khushhāl Khān and the book in Persian by the theologian Akhūnd Darweza (d. 1618/19 or 1638/39) "An Account of Pious and Wicked" (Tazkirat al-abrär wa-l-ashrär) which contains a report on the census conducted in the Yüsufzay tribe in the second quarter of the sixteenth century. The researched material includes data on the number of people in particular tribal units, birth dynamics, infant mortality and external negative factors, such as epidemics and natural disasters, that continuously affected demographic situation. The extant sources also shed light on family and matrimonial relations among Pashtuns in the sixteenth and seventeenth centuries. The facts examined in the article indicate that Pashtun tribal rulers were well familiar with the basics of practical demography which they needed to monitor the number of tribesmen while accomplishing specific administrative, military and economic tasks. The demographic notes left by the Khatak chieftains are to be considered among the most unique documents on the history and the culture of Pashtun tribes in early modern times.

Keywords: Pashtun tribes, demographic statistics, historiography, tribal chronicles, genealogies, Pashto literature.

Records on the size of the Pashtun tribes became available in the first half of the $19^{\text {th }}$ century, primarily, in publications of the British military officers $[1 ; 2 ; 3$, etc.]. These data originated from field reconnaissance and pursued quite obvious purposes. For example, Sir Alexander Burnes stated in his report of September 8, 1837: «The principal person among the Euzoofzyes is Futteh Khan, Chief of Punjtar, whose territories to the west are bounded by Swat and Hushtnuggur. He has about 1500 foot, and 200 horse, beside village (ooloosee) troops» [1, p.2]. Since 1871, numerous and broad-spectrum statistics on Pashtuns, including demographic characteristics, have been regularly published in British gazetteers, encyclopedic reference books on Afghanistan and North-West India. These gazetteers were compiled from materials of diverse multiple origins, including periodic

() Санкт-Петербургский государственный университет, 2019 
census reports and were intended initially as a "database" in support of activities of the British colonial administration; however, they reflected as well a wide range of areas and outcomes of these activities. While A. Burnes was chiefly interested in the military potential of Pashtun tribes measured by the number of horse and foot warriors, the compilers of the Gazetteer of the Peshawar District 1897-98 already neutral civil statistics: "Of the people no less than 339,069 persons, or 47,2 per cent., are true Pathans and 562,649 persons, or 90 per cent., speak Pashtu" [4, p. 125].

As evidenced by the extant written sources, a native-grown interest in demographic statistics emerged among Pashtuns three centuries earlier and it was also caused by practical needs. It should be noted that in other areas of knowledge related to studying the national history and culture, priority was also held by representatives of the Pashtun people. Probably, the most indicative fact in this respect refers to lexical and grammatical descriptions of the Pashto language made by the native speakers before the works of European researchers. The first-ever scientific treatises on Pashto grammar and vocabulary - "The Gardens of Mahabbat" (Riyā̇̇ al-Mahabbat), "Vocabulary of Irtiżā" (Farhang-i Irtiżà'i) and "Miracles of the Words" ('Ajä'ib al-lughät) were written in 1807, 1810, and 1813, respectively, by descendants of the Pashtun Diaspora in North India: Mahabbat Khān, Irtiżā Khān and Muḥammad Ilāhyār Khān. Meanwhile, the European works on Pashto grammar appeared only in $1840 \mathrm{~s}^{1}$.

The Pashtun tribes were mentioned in medieval sources written in Persian from the second half of the $10^{\text {th }}$ century, starting from the anonymous geographical tractate, "Boundaries of the World" (or "The Regions of the World;" Hudüd al-'àlam) (982/3) [9]. However, up to the establishment of the Great Mughal Empire in India in the first half of the $16^{\text {th }}$ century, Persian-speaking authors used to convey only brief and extremely scarce information about the Afghans and never called them by their historical endoethnonym "Pashtuns". Actually, the Pashtun tribes became an object of interest in Persian historiography through the memoirs of Zahīr al-Dīn Muhammad Bābur (1483-1530), the founder of the Mughal Empire, which were originally written in his native language (Chagatai, or Old Uzbek) and were promptly translated into multicultural Persian [10; 11, p. 151-167].

The first books in Pashto appeared almost at the same time as the memoirs of Bābur, in the second quarter of the $16^{\text {th }}$ century. These books did not survive to our time but their existence is reliably confirmed by the later Pashto sources. Apparently, they contained chronicles with diverse historical, economic and socio-legal records. The assumed authors of these books were the Yūsufzay tribal rulers Shaykh Malī and Kajū Khān. Their names appear in the titles, under which these books became known later: "The Record Book of Shaykh Malī" (Də Shaykh Malī daftar) and "The Chronicle of Khān Kajū" (Tārīkh-i Khān Kajü). The latter could have been originally entitled "Chronicles of the Afghans" (Tawārīkh-i afäghina) [12, p. 21-26]. Records of the Yūsufzay chiefs were preserved in the revised form in "The Chronicle of Hāfiz Raḥmat Khān” (Tārīkh-i Hāfiz-Raḥmat-Khānī), a historiographical work of the mid- $18^{\text {th }}$ century (1767). However, the written sources underlying this bilingual work were not represented by the original texts of the $17^{\text {th }}$ century but by their later narrations in Pashto in Persian [13; 14; 12, p. 66-67].

${ }^{1}$ First, the works of B.Dorn (1805-1881) were published in Saint-Petersburg [5; 6]; the papers of H. G. Raverty (1825-1906) were published later [7; 8]. B. Dorn's studies were based primarily on the copies of the Pashto grammar "The Gardens of Mahabbat". 
"The Record Book of Shaykh Malī" was of almost sacred value for the Yūsufzays. This is implied, for example, in caustic couplets by Khushḥāl Khān Khatak (1613-1689) dated to the mid-1670s, where "The Record Book" is compared with "The Treasury of Islam" (Makhzan al-Isläm), a theological work by Akhūnd Darweza (d. 1618/19 or 1638/39), acknowledged as the main book on the Muslim faith among the Yūsufzays and other Eastern Pashtuns [15, p.925]. J.Darmesteter (1849-1894) developed the same opinion after his mission to North India in the late $19^{\text {th }}$ century, when he heard from the local Pashtuns that a unique copy of Shaykh Malìs book was supposedly kept in secrecy in the Swàt mountains, away "from the ignorant eyes" [16, p. 184-185]. Later, based on implicit information, "The Record Book of Shaykh Mali”" was often defined as a "cadastral book," presumably containing a register of fertile lands in the Swàt valley and the procedures of their use [12, p. 24]. Probably, cadastral records made only part of "The Record Book," whereas other sections should have included Yūsufzay genealogies, historical information about the Yūsufzays relocation to Swāt, and, apparently, a summary of social and legal rules. In any case, "The Record Book of Shaykh Malī", the first book in Pashto, partly consisted of demographic records, which also included census statistics.

Pīr Mu'aẓzam Shāh, the author of "The Chronicle of Ḥāfiz Rạ̣mat Khān" mentioned that his primary source on the Yüsufzay history was the non-extant book "The Chronicles of Afghans" by Mìrdād Khalīl, written in Pashto and Farsi, ca. 1621/22. Presumably, this written work was the first synopsis of the old Yüsufzay books dated to the $16^{\text {th }}$ century. However, there is every reason to believe that materials presented in "The Record Book of Shaykh Malī" and "The Chronicle of Khān Kajü" had been used earlier by Akhūnd Darweza in his Persian work "An Account of Pious and Wicked" (Tazkirat al-abrär wal-ashrär), which is a mixture of religious sermons, memoirs and historical notes [17; 18, p. 26-39, 289-295]. Although Darweza does not refer to the earlier Pashtun sources, his information about the past of the Yüsufzays was obviously picked up from the books of Shaykh Malī and Kajū Khān, along with the oral traditions. Darweza provides a direct confirmation of the fact that Shaykh Mali dealt with the census in order to establish land use procedures. The quantitative evidence for the Yüsufzay clans was most likely extracted from written documents:

When the Yūsufzay tribe occupied the lands of Swāt, the Chief Shaykh Mali decided that it would be right to count tribal people - children and adults, men and women - and to divide Swāt according to their number. People [in the units] of Akozay and 'Isāzay made six thousand, and people [in the unit] of Mandar made twelve thousand more. And he included in the calculation people from Nangarhār, Laghmān and Kābul, who were with them, but did not include the people of these districts. According to this number, he made the division. Until now, this division of Shaykh Mali is unchanged, neither replaced, nor canceled [17, p. 106]².

2 Cf. translation of this excerpt made by V.V. Kushev from the manuscript (C 1560) stored in the IOM RAS collection [12, p. 23]. The text of the St. Petersburg manuscript bears a significant textual discrepancy related to statistical data; instead of "people [in the unit] of Mandar - made twelve thousand more" it states: "people [in the units] of Malizay and Ilyāszay — also made six thousand. [So] people [in the tribe] of Yūsufzay turned out twelve thousand". It may be assumed that these figures mean the number of families, rather than serfs. 
Demographic data on the size of tribal units were of paramount importance to tribal rulers. Military force, administrative and political influence, as well as economic potential of the units were largely determined by their numerical strength. Tax levies depended on the number of families. In cases where land ownership was public and agriculture was based on patriarchal land tenure, including the principle of regular redistribution of fertile land (among Pashtuns - wesh custom), the actual size of land holding of each clan unit also depended directly on the number of comprising families. These reasons dictated the census of Swāt land users implemented by Shaykh Mali, who could have recorded additionally the wesh rules in his "Record Book" [8, p.xv; 19, p. 125] $]^{3}$.

The most valuable and in many ways unique written source highlighting the everyday life of Pashtun tribes in the $17-18^{\text {th }}$ centuries is "The Khatak's Chronicle," a kind of home archive of the Khatak chieftains included by its author, Afżal Khān Khatak (1665/66 ca.1740/41), grandson of Khushḥāl Khān, in a compilatory historiographical work "The Ornamented History" (Tärìkh-i murașsạa) (completed in 1724) [21, p. 254-513]. Records of Khushḥāl and Afżal in the "The Chronicle" demonstrate the great practical importance of statistical data, including demography, for executing tribal rulers' military and administrative functions. The texts of "The Chronicle" abound with various quantitative indices suggesting that educated Pashtun chieftains counted much and often [22]. First and foremost, they counted people, both to assess the combat power of military units, and to evaluate the clan units' number in general. Pashtun chieftains had no taboo on counting people, though we know nothing about the attitude of ordinary tribesmen to such censuses $^{4}$.

The fundamental importance of demographic statistics in reports on the Pashtun tribes is well illustrated by a story from "The Chronicle" about a talk Khushḥāl Khān had with the Mughal Emperor Shāhjahān (1628-1658). This meeting took place on the lands of the Khatak Principality in 1649, when the Emperor was on his way to Kabul to take a lead of another Mughal military campaign at the western borders of the Empire. In the talk, which was only one step away from an interrogation, Shāhjahān showed immediate interest in demographic data - the number of the Yüsufzays, the northern neighbors of the Khataks, and their troops. Khushḥāl Khān reported to the Emperor that the Yūsufzays had eleven thousand families, and that the Swàt Yūsufzays can bring forward five thousand horsemen, and those from the Sama Valley - four or five hundred [21, p.278]. The same kind of information was reported by the British officer A. Burnes in 1837 (see above).

${ }^{3}$ According to O. Caroe, the land tenure order, which was established by Shaykh Mali and persisted in Swāt until the first half of the $20^{\text {th }}$ century, implied that land plots assigned to certain clans and defined by the term daftar (quite obviously, by the name of "The Record Book of Shaykh Malï"), were separated by plots granted specifically to tribal spiritual authorities, in order to prevent borderline conflicts [11, p. 182]. In the mid-17th century, Khushḥāl Khān Khatak, who observed the rules of feudal tenure of the Mughal Empire on his territories and was extremely dissatisfied with the old order of Shaykh Mali, briefly mentioned that in Swāt "Malik's fields are within the Daftar borders" that can be interpreted as an indirect allusion to the wesh custom [20, p. 32].

${ }^{4}$ Census data of the British colonial administration suggest that the Pashtuns were not eager to provide accurate information about their families, for many pragmatic reasons. Critical attitude to the very idea of counting people is reflected in the biblical story of King David, who took census of his people by Satan's incitement and was punished by God: "And (Joab) gave David the number of them, whom he had surveyed: and all the number of Israel was found to be eleven hundred thousand men that drew the sword: and of Juda four hundred and seventy thousand fighting men.... And God was displeased with this thing that was commanded: and he struck Israel" (The First Book of Paralipomenon, 21: p. 1-8). 
According to the records of the Khatak chiefs, tribal groups were considered "strong" or "weak" mostly depending on their number. For example, when describing the failed attempt of Jamāl Khān Mohmand to become tribal leader in 1710/11, Afżal Khān emphasizes that the warfare of this Mohmand chieftain was doomed to failure because of the weakness (i.e., the small number) of his native clan Mūsrīzay:

After the death of Padishah Aurangzeb, Jamāl Mohmand and some short-sighted fools with him, raised their heads to rebel. He was a Mūsrizzay among the Mohmands. And Mūsrizay is a weak clan (kamzore təpa) within the Mohmands. His goal was like that: "In this rebellion I will get honor and glory to myself, will gain power" [21, p.402].

The basic demographic unit of the Pashtuns was a family, household (kor); the numerical strength of tribal units was measured in the number of families. "The Khatak Chronicle" provides unique information about the number of families in all major Khatak clans. This demographic account is given in the first sections of "The Chronicle," which represent an exposition of draft records made by Khushhāl Khān. The list of the Khatak clans arranged in descending order (by number of families) is as follows: Gulzay - 2000, Amanzay - 1000, Sāgharay - 1000, İsoray-[Nușratī] — 500, Tsīnay — 400, Muhmanday - 400, Sīnay - 400, Ḥasankhel - 300, Babar - 300, Oryākhel - 300, Ghorīzay 300, Fatḥkhel - 250, Amanday — 250, Ismāîlkhel - 200, Achokhel — 200, Durmalik 200, Mūshak - 200, Khwaram-[Bolāq] - 200, Mughalkay - 200, Maḥmūtay - 180, Tsalozay - 150, Khwaram-[Tormān] - 100, Idrīshkhel - 100, Nandark - 100, Manday - 90, Radzar -60 , Hūnay -60 , Yūsufkhel $-50-60$, Amīr -52 , Watar -50 , Dangarzay - 50, Khwājakhel - 40 [21, p. 262, 266]. Thus, according to "The Chronicle", the number of the Khatak families at the eve of the $18^{\text {th }}$ century was about 9,690. This number correlates with the data on the Yūsufzays, eleven thousand families, as reported by Khushhāal Khān to Emperor Shāhjahān in $1649^{5}$.

Assuming that the minimum size of a nuclear family made five members, on average, the total number of the Khataks in the times of Khushḥāl Khān was at least fifty thousand. This number correlates remarkably with data of the Peshawar Gazetteer 1897-98, where the total number of the Khataks is estimated at 49,512 [4, p. 126]. However, the actual average number of a nuclear (married) family was probably greater than five. Moreover, the term kor could be applicable as well to the so-called "extended" family, which included relatives of various degrees of kinship, as well as servants and slaves; in this case, the number of family members could be even greater. Materials of "The Khataks' Chronicle" prevent an indisputable conclusion about the exact definition of kor, but it is little doubt that this term was based on the notion of a family consisting primarily of spouses and their offspring. In any case, relying on the demographic account made by Khushhāl Khān, it can be suggested that the actual number of the Khataks in the $17^{\text {th }}$ century exceeded significantly the fifty thousand minimum.

${ }^{5}$ Khushḥāl's data on the number of the Yūsufzays agree with those provided by Akhūnd Darweza in "An Account of Pious and Wicked" according to the St. Petersburg copy of the work. In the Peshawar edition of "An Account" the total number of the Yūsufzay families is estimated at about eighteen thousand (see above). 
Another number related to the demography of the Khataks was mentioned by Khushhạal Khān in his autobiographical poem "Come and listen to my story..." written in 1680. Here, Khushhial says the following: "Thirty thousand Khataks mine, / Each one to my word intent" [15, p. 582]. If Khushhāal means here the number of families, it is set too high, but if he means the total number of tribal members, it is underestimated. Given the poem context, it most likely implies the maximum number of combat strength, foot and horse, which the Khatak tribe could raise, according to their leader's calculations; all these are men of mature age, starting from 14-15 years old. It is noteworthy that the British military experts estimated the Khatak forces ("the number of the fighting men") in 1899 at twenty four thousand [3, p. 108]. Given that thirty thousand refers to men of mature age only, the total number of the Khatak tribe could amount up to one hundred thousand.

According to the detailed genealogical data presented in the first sections of "The Chronicle," the Khataks were subdivided into two large units - the Tormāns and the Bolāqs [21, p. 254-263]. The Tormān clans numbering 6,520 families dominated the Bolāq clans, which were less than twice (3,170 families). The Hasankhel clan, which included the Khatak ruling family Akorkhel, was average in size, but was the latest established within the general list of clans: its founder Hasan belonged to the latest generation of the clan eponyms. The demographic account mentions 300 Hasankhel families, though other Chronicle sections imply that there were about 200 families and the other 100 were probably the adjoined Miżhakhels. In the opinion of the Chronicle authors, clans consisting of 200 families were considered small: "Bakay has a few descendants, only two hundred families in total" [21, p. 261].

The priority importance of demographic indices in tribal relations is confirmed by the fact that the common names of certain tribal units were just numerals indicating the number of families. For example, two clans of the Dilāzāk tribe, whose founders were brothers Haydar and Sanay, had no separate eponymous names but both were known under the collective name "Sīṣada" (from Persian sī șad, "thirty hundred") [21, p. 255]. Obviously, this case indicates the merging of two close tribal groups with a total number of about three thousand families.

The number of members in each nuclear family depended mainly on the number of minor children and women - wives, concubines, unmarried and widowed female relatives of various degrees of kinship. Data of the Khatak lineages show that the number of children in the tribal elite varied strongly. For example, Nizām and Tāwus Khān, sons of Malik Akoray, great-grandfather of Khushḥāl, left no children ${ }^{6}$; Shahbāz Khān, father of Khushhāl, had four sons who reached the age of maturity; Yahyā Khān, grandfather of Khushḥāl, had eleven, and Khushḥāl Khān - thirty-one son ${ }^{7}$. If we compare representatives of the same generation, Khushḥāl's three full brothers - Shamshīr, Mīrbāz and Jamīl Beg - had one, six, and thirteen sons, respectively. Afżal Khān, who belonged to grandchildren of Khushhāl, mentions his four sons: fifteen, fourteen, eleven and nine years old, in his records dated 1718 [21, p. 417].

The Khatak chieftains' lineages bear no much information about daughters. The total number of Khushhiall's daughters (thirty-one, nameless, cf.ootnote 7) is indicated only and

${ }^{6}$ As regards Nizām, "The Chronicle" states that he "died young while his father was alive" [21, p. 257].

7 In his poem "The Book of Separation" (Firāq-nāma) written in 1665-66, Khushḥāl Khān tells that he has twenty-seven sons and thirty-two daughters [23, p. 34]. 
a daughter of Yūsuf Khān, one of the Akoray's sons, named Fātịma, is mentioned briefly [21, p. 257].

Fragmentary information about the wives and concubines of the Khatak chieftains, starting with Chinjo, great-great-grandfather of Khushhāl Khān, is also indicative of the absence of any "average statistic standards" in marital relations. "The Chronicle" reports that Chinjo had sons with two women, Malik Akoray — with seven, Yahyā Khān — with six, and Shahbāz Khān - with three. According to his own confession, Khushḥāl Khān had increased libido and, in addition to the four wives allowed by the Muslim marital laws, he also kept a large number of concubines [24, p. 166-167]. "The Chronicle" mentions his four Pashtun wives, whose names are unknown, and eleven concubines with the legal status of $u m m$ al-walad. This status guaranteed acknowledgement of paternity in respect of children born to the concubine from her owner and the appropriate subsistence level. One of the concubines, who gave birth to Farhat, son of Khushhāl, in 1668, during his forced stay in India, is identified as an "Indian" (hindūstānzy).

Female fertility also varied. Khushḥāl Khān had six adult sons with his first wife, daughter of Alif Alakkhel; two sons with both daughter of Dawlat Khān Kahtar and daughter of Șāhib Khān Muhmandzay, and one son with daughter of Malo Khān Bāyīzay. In certain cases, emphasis is put on the fact that a child "was the only (güxay) one to his mother" - as is said in "The Chronicle" about the three sons of Malik Akoray: halfbrothers Yahyyā Khān, Niz̄ām and Yūsuf Khān, whose mothers were Tārūka Mīżhakhel, Nandarko Bolāq and Durdāna Mohmand, respectively [21, p. 257].

The demographic situation in tribal units was greatly affected by a high rate of infant mortality that reached almost $1 / 2$. In other words, every second child did not survive to the age of maturity. "The Chronicle" provides exact information about the sons of Yahyā Khān and Khushḥāl Khān: the former had eleven sons, who lived to the age of maturity and "had nine children more, but they died in infancy (po tufüliyyat) [21, p. 257-258], while the extensive list of Khushhāl's sons mentions fifty-eight sons, of whom twentyseven died in infancy [21, p.260]. Of the twelve sons born to Khushhāl and his first wife, daughter of Alif Alakkhel, six died in infancy, and only one of the four sons born to a daughter of Malo Khān Bāyizay survived.

"The Chronicle" also contains detailed statistics on the age of infant mortality; the reported data almost exclusively refer to sons of Khushhāl Khān: four of them, including the firstborn Akbar, died within a week after birth, one son was aged one year old by death, one - aged two years, two sons - aged two-and-a-half years, one - by five years old, one - by eight, and one - by nine. One of Yahyā Khān's grandsons, i.e., the cousin of Khushḥāl, also died at the age of ten. Seven sons of Khushḥāl Khān died in premature delivery at the seventh or eighth month of pregnancy. In three cases, the dead babies were

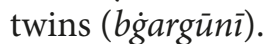

Persistent factors of negative impact on demography also included regular epidemics, natural disasters and famine caused by crop failures. These accidents are mentioned in "The Chronicle" only occasionally. For example, the story of Afżal Khān about the start of an unrest among the Pashtun tribes in the spring of 1695 tells sideways that "in that year, severe cholera ('azima wabā) emerged in this region, which apparently was the cause of the illness and death of the Kabul Governor Amīr Khān [21, p.489]. Khushhāl Khān mentions in his diary an epidemic of fever in the winter of 1673-1674 that struck his family refuging in the mountain fortress Takht (Taray-Bolāq territory). "Most people got sick 
with fever" (akșar tabzhan shawī wī) and his beloved daughter Tāj Bībī died [21, p. 315]. "The Chronicle" presents a story of Khushhāl's suffering from fever (təba) just before his wedding in the summer of 1631, a very exciting narration, both in artistic representation and with numerous ethnographic details [21, p.273].

Recalling the facts of natural disasters and epidemics are not rare also in Khushḥāl Khān's poetry, which partly represent diary records shaped in verse and complement the Chronicle records. Thus, the Khushhạl's diviann communicates on the three droughts that caused crop failure and large-scale famine in 1649, during the war for Kandahar between the Great Mughals and Iranian Safavids, in 1677, immediately after the end of the great Pashtun-Mughal war of 1672-76, and in the next year of 1678 [15, p. 578, 842-843, 904]. In the qit $a$-fragment about the drought of 1677, Khushhāl tells briefly of the demographic sequels of the famine-induced deaths: "Many children from the chieftain family (khelkhāna) died; / the stigma on the heart is [death of] 'Abdallāh, [son] of Yahyā Khān ${ }^{8 "}$.

A similar reference to drastic consequences of famine caused by the demographic factor (overpopulation) is found in personal memories of Akhūnd Darweza in "An Account of Pious and Wicked". The record refers to appr. 1591/92, when the Mughal Emperor Akbar (ca.1556-1605) conducted a military campaign against the Swāt Yūsufzays and neighboring districts of the south-eastern Hindu Kush. Akhūnd Darweza does not render statistical data on the victims but draws an impressive picture of the vast famine, which reveals the scale of this disaster and its impact on the demography over these territories [17, p.101-102]. This excerpt attracted the attention of Afżal Khān, who made a precise translation from Persian into Pashto and included it in the section of "The Ornamented History":

Finally, the Almighty God sent famine (qaht $)$ upon them (the Yüsufzays. - M. P.) and put under the wrath of Padishah [Akbar]. They were struck by famine to such an extent that they left both [valleys] - Sama and Būner - and got crowded in Swāt. Akhūnd Darweza tells that so many people died in Swăt every day, that the remaining had no strength to bury them. If they found carrion, they ate it as permitted food (haläl). They ate even dead flesh, if they could not find [carrion], and died. Men and women left each other, adults and children went away from each other. Out of hunger, they stole each other's children and sold them [into slavery] to other places. They stole things from each other and spent on food. To such an extent [it came to] that they lost everything they had [21, p. 240-241].

Two poems of Khushḥāl Khān, a qașìda and a qiț a, represent poetic responses to cholera epidemic of 1686-1687, which claimed many lives of his tribesmen, including members of his family [15, p. 506-507, 834-835]. In the qașìda, Khushḥāl not only calls to memory his deceased relatives, but also reports that in one case a hunting dog was the infection carrier:

Cholera of 1097 / May God not repeat! // My Akorkhels died off from it: / adults and children, men and women. // My [son] Bakhtnāk Khān died from it, / and ill fate took his mother. / One boy remained from him, / but soon he also died after them... // Also Sarfarāz, [son] of Sa ādat / good and beautiful was my grandson. // Learnt the Quran by heart / and was unequaled in literacy. / He raised a hunting dog, / and it got rabid quietly. / He held out his hand to it / because he took it as his friend. / But it bit his hand, / and this could not be cured. // In the same year ill fate / took him away from me [15, p. 506-507].

\footnotetext{
${ }^{8}$ Here, Yaḥyā Khān is a Khushāl's son named after his great grandfather.
} 
The qit ${ }^{\prime} a$-fragment is written in the genre of mourning elegy (marsiyya) and is entirely devoted to his son Bakhtnāk. Along with traditional posthumous praises and grievous exclamations, two facts are mentioned in the poem: Bakhtnāk's age - twenty-three years old, and the length of illness - two weeks.

Derived from several early Pashtun sources the above data relate to particular localities and provide a documentary corpus to study the outset of demography in certain Pashtun tribes only, in this case, the Khataks and the Yüsufzays. Second, these data reflect, to a limited extent, only basic elements of demography related to the size of ethnic groups and factors affecting demographic indices. The same sources contain the extensive genealogical and historical material allowing for a more detailed study within a wider range of topics related to the ethnogenesis and social demography of Pashtuns. As evidenced by data sources, mainly "The Khataks' Chronicle", the Pashtun tribal leaders had to make use of the basics of practical demography - first and foremost, since they needed to monitor the number of people in tribal units while performing specific military, administrative and economic tasks. Moreover, the very fact of the presence of demographic statistics in Pashto written sources dated back to the $16^{\text {th }}-17^{\text {th }}$ centuries adds them more value as the documents for studying the history and culture of Pashtun tribes in early modern times.

\section{References}

1. Reports and Papers, Political, Geographical and Commercial, Submitted to Government, by Sir Alexander Burnes, Bo. N. I.; Lieutenant Leech, Bo. E.; Doctor Lord, Bo. M. S.; and Lieutenant Wood, I. N., Employed on Missions in the Years 1835-36-37, in Scinde, Affghanisthan, and Adjacent Countries. Calcutta, G. H. Huttmann, Bengal Military Orphan Press, 1839. 200 p.

2. A Record of the Expeditions against the North-West Frontier Tribes, since the Annexation of the Punjab. Compiled from Official Sources, by Lieutenant-Colonel W.H. Paget, Commandant, 5th Punjab Cavalry, in 1873. Revised and Brought up to Date by Lieutenant A. H. Mason, Royal Engineers, in 1884. London, Whiting \& Co., 1884.679 p.

3. A Dictionary of the Pathan Tribes on the North-West Frontier of India, Compiled under the Orders of the Quarter Master General in India, in the Intelligence Branch. Calcutta, Government Printing, India, 1899. $239 \mathrm{p}$.

4. Gazetteer of the Peshawar district, 1897-1898. Lahore, Civil and Military Gazette Press, 1898. 392, p. xlvii.

5. Dorn B. Grammatische Bemerkungen über das Puschtu, oder die Sprache der Afghanen. Mémoires de l’Académie Impériale des Sciences de St. Pétersbourg, 1840, VI série, T. 5, pp. 1-163.

6. Dorn B. Nachträge zur Grammatik der afghanischen Sprache. Bulletin scientifique de l'Académie impériale de Saint-Pétersbourg, 1842, T. 10, no. 23, pp. 356-368.

7. Raverty H.G. A Grammar of the Puk'hto, Pus'hto, or Language of the Afghans. $2^{\text {nd }}$ ed. London, Longman, Green, Longman and Roberts, 1860. xvi, 204 p.

8. Raverty H. G. A Dictionary of the Puk'hto, Pus'hto, or Language of the Afghans, with Remarks on the Originality of the Language, and its Affinity to Other Oriental Tongues. $2^{\mathrm{n}} \mathrm{d}$ ed. London, Williams and Norgate, 1867. xxiv, $1166 \mathrm{p}$.

9. Hudūd al-'Ālam. The Regions of the World: a Persian Geography, 372 A.H.-982 A.D. $2^{\text {nd }}$ ed. Translated and explained by V.Minorsky, with the preface by V.V.Barthold, ed. by C.E. Bosworth. London, Luzac \& Co., 1970. 524 p.

10. The Bābur-nāma in English (Memoirs of Bābur). Vol. I-II. Transl. by A.S. Beveridge. London, Luzac \& Co., 1922.512 (I), 542 (II) p.

11. Caroe O. The Pathans, 550 B.C.-A.D. 1957. London, Macmillan \& Co., 1958. 521 p.

12. Kushev V.V. Afganskaia rukopisnaia kniga (ocherki afganskoi pis'mennoi kul'tury) [Afghan HandWritten Book (Essays on the Afghan Writing Culture)]. Moscow, Nauka Publ., GRVL Publ., 1980. 192 p. (In Russian)

13. Pīr Mu'aẓzam Shāh. Tārīkh-i Hāfiż-Rahmat-Khānī. Introduction by M.Nawāz Ṭāyīr. Peshawar, Pashto Academy, University of Peshawar, 1971. vii, xxxv, 188 p. (In Pashto) 
14. Nichols R. Reclaiming the past. The Tawarikh-i Hafiz Rahmat Khani and Pashtun historiography. Afghan history through Afghan eyes. Ed. by N. Green. New York, Oxford University Press, 2015, pp. 211-234.

15. Khushḥ̄l Khān Khatak. Kulliyāt [Collected poetry]. Introduction and notes by D. M. Kāmil Momand. Peshawar: Idāra-yi ishāàt-i sarḥadd-i Pishāwar, 1952. 968 p. (In Pashto)

16. Darmesteter J. Chants populaires des Afghans. Paris, Imprimerie nationale, E. Leroux, 1888-1890. ccxviii, 299, $228 \mathrm{p}$.

17. Akhūnd Darweza. Tazkirat al-abrār wa-l-ashrār [An Account of Pious and Wicked]. Peshawar, Idārayi ishāatat-i sarḥadd-i Pishāwar, 1960. 248 p. (In Persian)

18. Nichols R. Settling the Frontier. Land, law and society in the Peshawar valley, 1500-1900. Karachi, Oxford University Press, 2001. 321 p.

19. Aslanov M.G. Narodnoe dvizhenie roshani i ego otrazhenie v afganskoi literature XVI-XVII vv. [The People's Roshani Movement and its Reflection in Afghan Literature]. Sovetskoe vostokovedenie, 1955, no. 5, pp. 121-132. (In Russian)

20. Khushḥāl Khān Khatak. Swāt-nāma [The Book about Swat]. Introduction and notes by 'A. Habībī. Kabul, Zeray Weekly, Academy of Sciences of Afghanistan, 1979. lxxvii, 70. (In Pashto)

21. Afżal Khān Khatak. Tärīkh-i murașşa' [The Ornamented history]. Ed. with preface and notes by D. M. Kāmil. Peshawar, University Book Agency, 1974. 1494 p. (In Pashto)

22. Pelevin M. Daily Arithmetic of Pashtun Tribal Rulers: Numbers in The Khataks' Chronicle. Iran and the Caucasus, 2016, vol.20, no. 1, pp. 63-83.

23. Khushḥāl Khān Khatak. Firāq-nāma [The Book of separation]. Ed. with preface, commentaries and glossary by Z. Hewādmal. Kabul, Kabul University, 1984. 10, p. xlviii, 72, lxii. (In Pashto)

24. Pelevin M. S. Khushkhal-khan Khattak (1613-1689). Nachalo afganskoi natsional'noi poezii [KhushhalKhan Khattak (1613-1689). The Beginning of Afghan National Poetry]. St. Petersburg, Peterburgskoe vostokovedenie Publ., 2005. 286 p. (In Russian)

Received: September 17, 2018 Accepted: December 6, 2018

Author's information:

Mikhail S.Pelevin — Dr. Sci. in Philology, Professor; mosprolege@gmail.com

\title{
Демографическая статистика у афганцев на рубеже Средневековья и Нового времени
}

\author{
М. С. Пелевин \\ Санкт-Петербургский государственный университет, \\ Российская Федерация, 199034, Санкт-Петербург, Университетская наб., 7-9
}

Для цитирования: Pelevin M. S. Demographic Statistics among Pashtuns in Early Modern Period // Вестник Санкт-Петербургского университета. Востоковедение и африканистика. 2019. Т. 11. Вып. 1. С. 64-74. https://doi.org/10.21638/spbu13.2019.105 (In English)

В статье собраны и прокомментированы редкие образцы демографической статистики из произведений XVII в. на языках пашто и персидском, созданных непосредственно на территориях паштунских племен. Главным источником являются хроникальноисторические и генеалогические записи вождей племени хатак Хушхал-хана (ум. 1689) и Афзал-хана (ум. ок. 1740/41). Эти записи сохранились в «Хатакской хронике» - архиве хатакских вождей, включенном Афзал-ханом в качестве приложения в его историографическую компиляцию «Украшенная драгоценностями история» (Tärīkh-i murașșa). Дополнительно были привлечены поэтические произведения Хушхал-хана и некоторые разделы из персоязычного сочинения богослова Ахунда Дарвезы (ум. 1618/19 или 1638/39) «Повествования о праведных и злых» (Tazkirat al-abrār wa-l-ashrār), где 
сообщается о переписи, проведенной в племени йусуфзай во второй четверти XVI в. Исследуемые материалы содержат уникальные данные о количестве членов отдельных племенных подразделений, динамике рождаемости и детской смертности, внешних негативных факторах - эпидемиях и стихийных бедствиях, постоянно влиявших на демографические показатели. Сведения из источников позволяют получить более ясное представление о семье и брачных отношениях у паштунов в XVI-XVII вв. Анализ приведенных фактов показывает, что афганские племенные правители владели основами практической демографии, необходимой им для мониторинга численного состава племенных подразделений при выполнении конкретных военных, административных и хозяйственных задач. Сохранившиеся демографические справки хатакских князей имеют исключительную ценность как документы по истории и культуре паштунских племен на рубеже Средних веков и Нового времени.

Ключевые слова: паштунские племена, демографическая статистика, историография, племенные хроники, генеалогии, литература пашто.

Контактная информация:

Пелевин Михаил Сергеевич - д-р филол. наук, проф.; mosprolege@gmail.com 